(c) American Dairy Science Association, 2006.

\title{
Evaporative Tunnel Cooling of Dairy Cows in the Southeast. II: Impact on Lactation Performance ${ }^{1}$
}

\author{
T. R. Smith, ${ }^{\star 2}$ A. Chapa, ${ }^{\star}$ S. Willard, ${ }^{\star}$ C. Herndon Jr.,† R. J. Williams, ${ }^{\star}$ J. Crouch, ${ }^{\star}$ T. Riley,‡ and D. Pogueł \\ ${ }^{*}$ Department of Animal and Dairy Sciences, and \\ †Department of Agricultural Economics, Mississippi State University, Starkville 39762 \\ $\ddagger$ North Mississippi Branch Experiment Station, Holly Springs 38635
}

\section{ABSTRACT}

Heat stress has a dramatic impact on the dairy industry, reducing production and profitability throughout the southeastern United States. In many regions, management techniques can be used to mitigate the effects of heat stress, but available cooling technologies are often overwhelmed by the conditions of chronic heat stress present in southeastern United States. Although combining tunnel ventilation and evaporative cooling (evaporative tunnel cooling) seems to provide superior cooling for dairy cows, there is a dearth of reports on the impact of this technology on milk production. A model evaporative tunnel cooling facility in northern Mississippi was studied using 2 groups of 10 lactating Holstein cows housed in the tunnel barn and 2 groups of 10 matched herdmates housed in an adjacent naturally ventilated free-stall barn. Two 10 -wk trials were performed in $2 \mathrm{yr}$ beginning June 25, 2001, and May 26, 2003, in which cows housed outside were cooled by traditional fans and shade alone (2003) or with sprinklers (2001). In both years, the use of evaporative tunnel cooling decreased exposure to conditions of moderate heat stress by $84 \%$. Cows cooled by evaporative tunnel ventilation increased feed intake by 12 and $11 \%$ over cows housed outside in 2001 and 2003, respectively. Evaporative tunnel cooling had no effect on milk composition, but increased milk yield over the 10 -wk trial by $2.6 \pm 0.27$ and $2.8 \pm 0.19 \mathrm{~kg} / \mathrm{cow}$ per day in 2001 and 2003, respectively. In addition, somatic cell count was decreased 27 to $49 \%$ by evaporative tunnel cooling. Thus, under the range of environmental conditions present, evaporative tunnel cooling reliably reduced exposure to conditions of heat stress and improved milk production of lactating dairy cows during the summer season.

Received October 11, 2005

Accepted March 1, 2006

${ }^{1}$ Approved for publication as Journal Article No. J-10800 of the Mississippi Agricultural and Forestry Experiment Station, Mississippi State University.

${ }^{2}$ Corresponding author: TRSmith@ads.msstate.edu
Key words: heat stress, tunnel ventilation, evaporative cooling, milk yield

\section{INTRODUCTION}

\section{Heat Stress}

Lactating dairy cows are extremely sensitive to heat stress because of their large body size and high metabolic rate. Characteristic signs of heat stress in dairy cows include an increased rectal temperature and respiratory rate and decreased feed intake (Ingraham et al., 1975; Fuquay, 1981). Thus, chronic heat stress can decrease milk production as much as 10 to $20 \%$, and the symptoms of heat stress are exacerbated in higherproducing dairy cows (Igono and Johnson, 1990). Because the effects of elevated temperatures on dairy cows are compounded by high humidity, the temperature-humidity index (THI) is used to predict their combined effects (Igono et al., 1992; Ravagnolo and Misztal, 2000). Lactating dairy cows begin to suffer mild heat stress at a THI of 72 , which corresponds to $22^{\circ} \mathrm{C}$ when relative humidity is elevated, and to over $27^{\circ} \mathrm{C}$ when humidity is low (Armstrong, 1994; West, 2003). Cows become moderately heat stressed at THI $>80$ and severely heat stressed at THI $>90$.

Physical methods to alleviate the effect of heat stress in dairy cattle include shade, fans, and sprinklers, and dietary modifications can be used to maintain nutrient intake during periods of heat stress (Beede and Collier, 1986; Armstrong et al., 1999), but these methods are often overwhelmed during periods of severe heat stress. In addition, they can cause problems; excessive dietary protein can increase the generation of metabolic heat (West, 2003) and excess water from misters and cooling ponds may contaminate the teat ends and increase the incidence of mastitis (Smith, 1983).

\section{Evaporative Tunnel Cooling}

Tunnel ventilation is relatively new to the dairy industry, but this technology is used extensively for cooling swine and poultry facilities. Characterized as having air inlets at one end of the barn and exhaust fans 
at the other, tunnel ventilation technology works to enhance convective heat loss by removing excess heat and humidity from the immediate surroundings of animals. Tunnel ventilation alone can provide adequate supplemental cooling in temperate environments (Stowell et al., 2001), but can also be combined with other cooling methodologies such as misters, sprinklers or evaporative coolers in regions where additional cooling is required (Turner et al., 1991). Evaporative coolers work to remove heat from the incoming air by promoting water evaporation. There is evidence that evaporative tunnel cooling (tunnel ventilation combined with evaporative cooling cells) provides superior cooling and growth performance in swine and poultry (Simmons et al., 1997; Lally and Edwards, 2001). Brouk et al. (2003) used tunnel ventilation with evaporative cells to cool lactating dairy cows in northeast Missouri and reported that afternoon and evening respiration rates and rectal temperatures were significantly reduced when compared with cooling with tunnel ventilation alone. However, there has been no published work describing the impact of this technology on milk production or on the feasibility and efficacy of adapting evaporative tunnel cooling for the dairy industry. The data reported herein are part of a larger project to characterize the efficacy of evaporative tunnel cooling. Thus, the objective of this project was to test the efficacy of evaporative tunnel ventilation for cooling dairy cows in the southeastern United States.

\section{MATERIALS AND METHODS}

\section{Cows}

The effects of evaporative tunnel cooling on milk production were studied over 2 summer seasons (2001 and 2003). In each year, 40 lactating Holstein cows were randomly assigned to 1 of 4 groups; 2 groups were housed in the tunnel barn (inside groups) and the remaining 2 groups were housed in an adjacent, naturally ventilated free-stall barn (outside groups). The experimental groups were balanced for DIM, parity, and production. The 10 -wk lactation trials were conducted from June 25 to September 3, 2001, and from May 26 to August 1, 2003. Cows housed inside were cooled by evaporative tunnel ventilation, whereas cows housed outside were cooled by shade and fans alone (2003 trial) or combined with sprinklers (2001 trial). Table 1 lists the characteristics of cows used in both treatment groups in each year of the trial. All cows were injected with Posilac every $14 \mathrm{~d}$ during the study as part of the routine production practice at Holly Springs. All animal protocols were approved by the Institutional Animal Care and Use Committee (IACUC approval \# 01-061).
All cows received a partially mixed ration (PMR) of $60.4 \%$ corn silage, $16.9 \%$ corn grain, $9.1 \%$ whole cottonseed, $8.4 \%$ soybean hulls, $2.4 \%$ vitamin and mineral premix, 2.1\% Prolak (HJ Baker and Sons, Inc., Stamford, CT), and $0.70 \%$ Megalac (Church and Dwight Co., Princeton, NJ). The PMR averaged 1.72 Mcal of $\mathrm{NE}_{\mathrm{L}} / \mathrm{kg}, 13.1 \% \mathrm{CP}, 22.4 \% \mathrm{ADF}$, and $36.4 \%$ NDF. Bermudagrass hay was added to the top of the diet at $0.91 \mathrm{~kg} / \mathrm{d}$ per cow in both years of the trial and cows consumed all that was offered. Cows were fed by group twice daily ad libitum to achieve $7 \%$ refusals. Feed intake and refusals were measured daily and fresh water was available at all times.

\section{Housing Facilities}

The model evaporative tunnel ventilation barn constructed at the North Mississippi Branch Experiment Station in Holly Springs contained feed bunks, water tanks, free-stall bedding areas, controlled lighting, and waste management flush tanks to support 20 mature Holstein dairy cows. The $27.5 \times 9.2 \mathrm{~m}$ barn was outfitted with two 7.6-m evaporative cooling cells (AeroTech Inc.; Evans, GA) at one end and four 1.2m, 1-horsepower exhaust fans (Advantage; AeroTech Inc.) at the other. The 4 exhaust fans were thermostatically controlled and set to come on sequentially at 18.3 , $21.1,23.9$, and $26.7^{\circ} \mathrm{C}$. The pumps used to cycle water over the cooling cells were set to come on at $21.1^{\circ} \mathrm{C}$. Thus, fresh air was cooled as it entered the barn through the cooling cells and then flowed past the cows before being exhausted at the far end. Along one side of the tunnel barn were free stalls for 20 cows, which were bedded with sand. Along the other wall were feed bunks and automatic water troughs. Lighting in the tunnel barn was set for a $12: 12 \mathrm{~h}$ cycle and cows received additional ambient light through the windows, which lined both sides of the barn. The entire barn was divided into 2 pens with a central gate. Additional details of the barn's structure and cooling characteristics are described in the companion article (Smith et al., 2006).

The outside free-stall housing units were open-sided permanent shelters, with $2.13-\mathrm{m}$ eaves and $3.66-\mathrm{m}$ vented ridges (Smith et al., 2006).

\section{Environmental Measures}

Environmental temperature and humidity was recorded every 2 min in both housing units using Hobo (Onset Computer Corp., Pocasset, MA) monitors.

\section{Animal Measures}

This study was part of a larger trial to study the potential of evaporative tunnel ventilation technology 
Table 1. Pretrial characteristics of cows housed in the tunnel barn (inside) and in an adjacent, naturally ventilated free-stall barn (outside) at the onset of the trials in 2001 and $2003^{1}$

\begin{tabular}{|c|c|c|c|c|}
\hline \multirow[b]{2}{*}{ Variable } & \multicolumn{2}{|c|}{2001 trial } & \multicolumn{2}{|c|}{2003 trial } \\
\hline & Inside & Outside & Inside & Outside \\
\hline $\mathrm{n}$ & 20 & 20 & 20 & 20 \\
\hline BW, kg & $665 \pm 24$ & $674 \pm 19$ & $652 \pm 18$ & $682 \pm 15$ \\
\hline $\mathrm{BCS}^{2}$ & $3.1 \pm 0.16^{\mathrm{a}}$ & $3.2 \pm 0.12^{\mathrm{a}}$ & $3.4 \pm 0.12^{\mathrm{a}}$ & $3.8 \pm 0.11^{b}$ \\
\hline Parity & $2.3 \pm 0.40$ & $2.4 \pm 0.29$ & $2.2 \pm 0.21$ & $2.2 \pm 0.21$ \\
\hline Preceding days dry ${ }^{3}$ & $48 \pm 3.7$ & $45 \pm 2.4$ & $61.8 \pm 1.4$ & $74.9 \pm 10.2$ \\
\hline DIM & $208 \pm 12$ & $216 \pm 13$ & $210 \pm 8$ & $215 \pm 12$ \\
\hline Milk production, kg/d ${ }^{4}$ & $33.8 \pm 5.9$ & $33.4 \pm 5.6$ & $34.5 \pm 4.4$ & $34.2 \pm 7.6$ \\
\hline Milk fat, $\%^{4}$ & $3.5 \pm 0.31$ & $3.5 \pm 0.31$ & $3.4 \pm 0.15$ & $3.4 \pm 0.22$ \\
\hline Milk protein, $\%$ & $3.1 \pm 0.20$ & $3.1 \pm 0.28$ & $2.9 \pm 0.10$ & $3.0 \pm 0.09$ \\
\hline Predicted 305-d ME ECM, ${ }^{4,5} \mathrm{~kg}$ & $10,321 \pm 415$ & $10,078 \pm 399$ & $10,814 \pm 289$ & $10,942 \pm 353$ \\
\hline \multirow{2}{*}{\multicolumn{5}{|c|}{$\begin{array}{l}\mathrm{a}, \mathrm{b} \\
0.05)\end{array}$}} \\
\hline & & & & \\
\hline \multicolumn{5}{|c|}{${ }^{1}$ Data represent the least squares means $\pm \mathrm{SE}$ of cows in each group. } \\
\hline \multicolumn{5}{|c|}{${ }^{2}$ Based on the 5-point scale of Wildman et al. (1982). } \\
\hline \multicolumn{5}{|c|}{${ }^{3}$ Calculation excludes primiparous cows. } \\
\hline \multicolumn{5}{|c|}{${ }^{4}$ Pretrial milk production and composition data was from DHI tests of May 7, 2001 and April 5, 2003.} \\
\hline $\begin{array}{l}{ }^{5} \text { Mature equivalent (ME) ECM } \\
\text { 305-d ME protein (Tyrrell and }\end{array}$ & $\begin{array}{l}\text { vas calculated as } \\
\text { eid, 1965). }\end{array}$ & $3246 \times 305-\mathrm{d} \mathrm{Ml}$ & milk $+12.86 \times 30$ & \\
\hline
\end{tabular}

for cooling dairy cows in the southern United States. Details of the evaporative tunnel barn, and its impact on environmental conditions, body temperatures, and respiration rates are described in Smith et al. (2006). Individual milk production was recorded daily and samples were collected weekly from each cow for determination of fat, protein, lactose content and SCC. Analysis of milk composition was performed by the DHI laboratory in Baton Rouge, LA. Body weight and BCS (determined by T. Riley, the dairy herdsman) were measured on Monday of each week between 0900 and $1100 \mathrm{~h}$. At the same time, blood samples were collected for analysis of plasma glucose and NEFA concentrations. If cows were out of the barn for any reason, they were allowed at least $1 \mathrm{~h}$ to acclimate after being returned before the physiological measurements were taken.

\section{Statistical Analysis}

Data were analyzed as a completely randomized design with repeated measures using the Mixed procedure of SAS (SAS Institute, 1999). Data for the $2 \mathrm{yr}$ were analyzed separately and the experimental unit was considered to be the pen within the barn, so the statistical design included the fixed effects of barn and pen as well as the random effect of week. A $P$-value < 0.05 was considered statistically significant. In the 2001 trial, 2 cows housed inside the tunnel barn left the study in the first week with digestive upset (detailed under Cow Behavior below) and were not replaced. Another 2 cows (1 from each treatment group) left the 2001 study in the seventh week when it became necessary to dry them off. Data for these cows were included in the results up to the point when they left the study.

\section{RESULTS AND DISCUSSION}

\section{Cow Behavior}

When cows were first introduced into the evaporative tunnel barn, they were reluctant to enter, probably because of the new structure and the unfamiliarity with the drone of the fans and the low ceilings. However, within $2 \mathrm{~d}$, their behavior had changed dramatically; they waited eagerly to reenter the barn after being let out for milking. As noted above, in the first year of the trial (2001), 1 cow from each pen inside the tunnel barn was diagnosed with a displaced abomasum during the first week of the trial and they were removed from the trial without being replaced. A third cow developed a digestive upset soon after entering the tunnel barn, but recovered quickly after surgery for a displaced abomasum and remained on the trial. The normal practice at the Holly Springs dairy was to bed cows on rubber mats. Thus, the sand bedding in the tunnel barn was new to these cows. The cows with digestive upsets were observed to have eaten sand. The digestive upsets were not deemed to be a problem with the tunnel ventilation facility per se.

\section{Environmental Conditions}

Ambient conditions present at the North Mississippi Branch Experiment Station in Holly Springs are presented in Table 2 for each year of the trial. The temper- 
Table 2. Environmental conditions in the tunnel barn (inside) and an adjacent, naturally ventilated freestall barn (outside) during the 2001 and 2003 trials $^{1}$

\begin{tabular}{|c|c|c|c|c|}
\hline \multirow[b]{2}{*}{ Variable } & \multicolumn{2}{|c|}{2001 Trial } & \multicolumn{2}{|c|}{2003 Trial } \\
\hline & Inside & Outside & Inside & Outside \\
\hline Minimum temperature, ${ }^{\circ} \mathrm{C}$ & $27.1 \pm 0.25$ & $28.0 \pm 0.27$ & $19.8 \pm 0.27$ & $19.4 \pm 0.40$ \\
\hline Maximum temperature, ${ }^{\circ} \mathrm{C}$ & $33.0 \pm 0.20$ & $38.2 \pm 0.29$ & $25.4 \pm 0.26$ & $30.4 \pm 0.35$ \\
\hline Daytime $\mathrm{RH}^{2} \%$ & $91.1 \pm 0.26$ & $64.4 \pm 15.2$ & $93.5 \pm 0.40$ & $71.3 \pm 0.94$ \\
\hline Minimum $\mathrm{THI}^{3}$ & $69.6 \pm 0.45$ & $70.7 \pm 0.46$ & $67.5 \pm 0.49$ & $66.6 \pm 0.71$ \\
\hline Maximum THI & $79.2 \pm 0.35$ & $82.1 \pm 0.31$ & $76.5 \pm 0.46$ & $79.6 \pm 0.46$ \\
\hline
\end{tabular}

${ }^{1}$ Ten-week lactation trials were conducted from June 25 through September 3, 2001, and from May 26 through August 1, 2003. Data were summarized from observations recorded every 2 min throughout the trials as described in Materials and Methods.

${ }^{2}$ Daytime relative humidity $(\mathrm{RH})$ was calculated from measurements taken between 1000 and $1800 \mathrm{~h}$.

${ }^{3}$ Temperature-humidity index (THI) was calculated as $\left[\left(0.8 \times{ }^{\circ} \mathrm{C}\right)+\mathrm{RH} / 100 \times\left({ }^{\circ} \mathrm{C}-14.44\right)\right]+46.4$ (Ravagnolo and Misztal, 2000).

ature in the tunnel ventilation barn paralleled the outside temperature until pumps began to recirculate water over the cooling cells $\left(21.1^{\circ} \mathrm{C}\right)$. During the trial in 2001 , the peak daytime temperature inside was 5.2 $\pm 0.18^{\circ} \mathrm{C}$ below that in the outside free-stall barns $(P$ $<0.0001)$. In the 2003 trial, ambient conditions were cooler, but peak daytime temperatures inside remained $4.9 \pm 0.23^{\circ} \mathrm{C}$ below that in the outside freestall barns $(P<0.0001)$. Thus, evaporative tunnel cooling acted to decrease maximal daytime temperatures inside; it also increased $(P<0.0001)$ relative humidity by $24.7 \pm 0.42 \%$ and $22.3 \pm 0.64 \%$ above that in the outside freestalls in 2001 and 2003, respectively. These factors combined to reduce $(P<0.0001)$ the maximum daytime THI within the tunnel barn by $2.9 \pm 0.06$ to $3.1 \pm 0.05$ units; this reduction had an impact on exposure to heat stress.

There were no conditions of severe heat stress during either year studied. Evaporative tunnel cooling re- duced exposure to moderate heat stress by $84 \%$ during both years (Figure 1). Conversely, the time spent in less stressful conditions was increased (Table 3) and exposure to thermoneutral conditions was increased $(P<0.0001)$ by $52 \pm 8.7 \%$ and $26 \pm 3.6 \%$ for animals in the tunnel barn during 2001 and 2003, respectively. A more detailed analysis of the environmental conditions during the trials and the effect of evaporative tunnel cooling on body temperature and respiratory rate in lactating dairy cows is published in a companion paper (Smith et al., 2006).

\section{Feed Intake}

In 2001 , intake of the PMR was $17 \%$ greater $(P<$ 0.001 ) for cows housed in the tunnel barn during wk 1 to 5 than for cows housed outside (Figure 2). After wk 5 , intake rebounded in cows housed outside. Cows housed inside had $2 \mathrm{~kg} / \mathrm{d}$ lower intake in wk 6 and 7
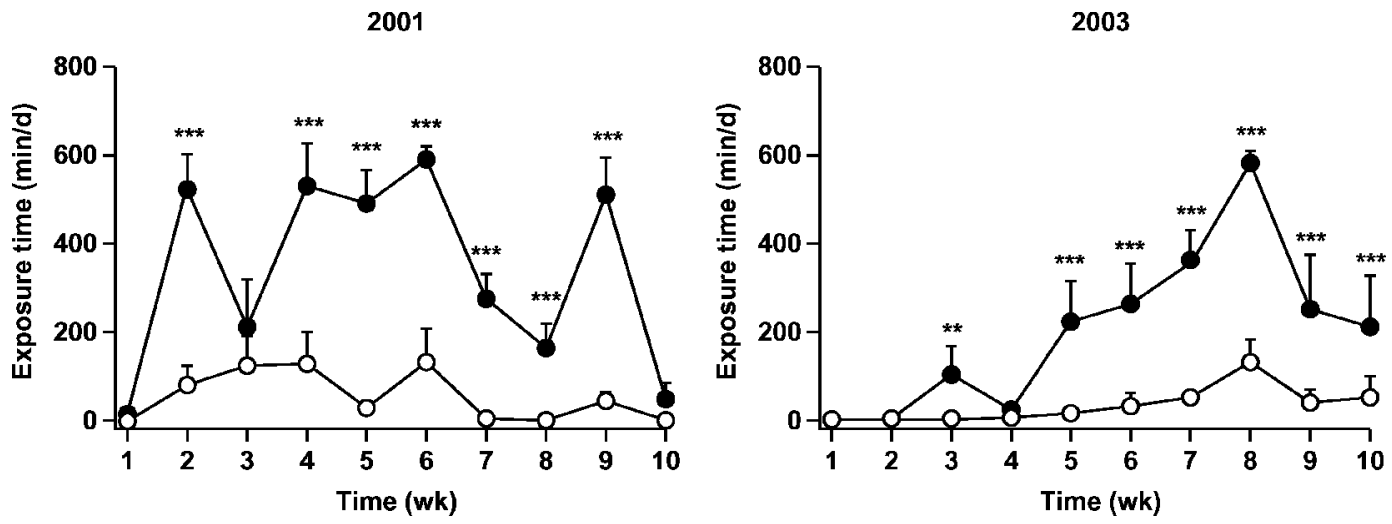

Figure 1. The duration $(\mathrm{min} / \mathrm{d})$ of exposure to conditions of moderate heat stress [temperature-humidity index (THI) < 80] during the 2001 and 2003 seasons for cows housed in the tunnel barn (inside; $\bigcirc$ ) or in an adjacent, naturally ventilated free-stall barn (outside; 0 ). The trials were conducted from June 25 through September 3, 2001, and from May 26 through August 1, 2003. The THI was calculated as $\left[\left(0.8 \times{ }^{\circ} \mathrm{C}\right)+\mathrm{RH} / 100 \times\left({ }^{\circ} \mathrm{C}-14.44\right)\right]+46.4(\mathrm{NOAA}, 1976)$. Data represent the mean and $\mathrm{SE}$ of daily observations calculated from data recorded every 10 min throughout the trials as described in Materials and Methods. 
Table 3. Average time of exposure ( $\mathrm{min} / \mathrm{d}$ ) to conditions of heat stress for cows housed in the tunnel barn (inside) and in an adjacent, naturally ventilated free-stall barn (outside) during the 2001 and 2003 trials at the North Mississippi Branch Experiment Station in Holly Springs ${ }^{1}$

\begin{tabular}{|c|c|c|c|c|}
\hline \multirow[b]{2}{*}{ Stress range $^{2}$} & \multicolumn{2}{|c|}{2001} & \multicolumn{2}{|c|}{2003} \\
\hline & Inside & Outside & Inside & Outside \\
\hline Moderate $(80<\mathrm{THI}<90)$ & $54 \pm 14$ & $335 \pm 23$ & $32 \pm 9$ & $206 \pm 32$ \\
\hline Mild $(70<$ THI < 80) & $1,011 \pm 43$ & $858 \pm 29$ & $732 \pm 52$ & $697 \pm 39$ \\
\hline Thermoneutral (THI < 70) & $375 \pm 46$ & $246 \pm 35$ & $676 \pm 56$ & $537 \pm 49$ \\
\hline
\end{tabular}

\footnotetext{
${ }^{1}$ Trials were conducted from June 25 to September 3, 2001, and from May 26 to August 1, 2003. Data were calculated from observations recorded every $10 \mathrm{~min}$ in both housing units as described in Materials and Methods.

${ }^{2}$ The temperature-humidity index (THI) was calculated as $\left[\left(0.8 \times{ }^{\circ} \mathrm{C}\right)+\mathrm{RH} / 100 \times\left({ }^{\circ} \mathrm{C}-14.44\right)\right]+46.4$ (Ravagnolo and Misztal, 2000). There were no conditions of severe heat stress recorded during either year of the study.
}

than during wk $1(P<0.05)$, but the drop in intake did not appear to coincide with any heat-stress event. Intake was similar between treatments during wk 6 to 8. Intake recovered for cows housed inside during wk 9, whereas that for cows housed outside declined with another heat-stress event. As a result, during 2001, PMR intake for cows housed in the tunnel barn was $1.9 \pm 0.31 \mathrm{~kg} / \mathrm{d}$ per cow, or $12 \%$ greater than for cows housed outside $(P<0.05)$.

In 2003, PMR intake for the cows housed inside the tunnel barn was greater than for cows housed outside beginning at wk 2 and remained elevated until wk 7. During wk 8, when environmental conditions were most severe (outside exposure to moderate heat stress conditions was $9.6 \pm 1.3 \mathrm{~h} / \mathrm{d}$; Figure 1), intake was similar between treatments. By wk 10, cows housed outside seemed to take advantage of the relatively cooler weather (outside exposure to moderate heatstress conditions was $3.0 \pm 4.6 \mathrm{~h} / \mathrm{d}$ ) to compensate for the prolonged period of depressed intake. As a result, during 2003, PMR intake for cows housed in the tunnel barn was $1.6 \pm 0.36 \mathrm{~kg} / \mathrm{d}$ per cow, or $11 \%$ greater than for those housed outside $(P<0.05)$. Despite the presence of shade and fans and considerably cooler environmental conditions in 2003, the increment in intake between treatment groups was similar in both years. These data suggest that evaporative tunnel cooling can provide superior cooling to the use of shade and fans alone or when combined with sprinklers.

The association between thermoregulation and feed intake is not new, and data from the present study are consistent with that of other researchers in demonstrating the negative impact of heat stress on feed intake in lactating dairy cows (Hahn et al., 1992). Although reduced feed intake is part of the adaptive mechanism used to reduce heat production, it has been identified as a major cause of reduced milk production for heatstressed dairy cows (Fuquay, 1981; West, 2003). Moreover, studies have noted a shift in the pattern of feed intake induced by heat stress toward more small meals
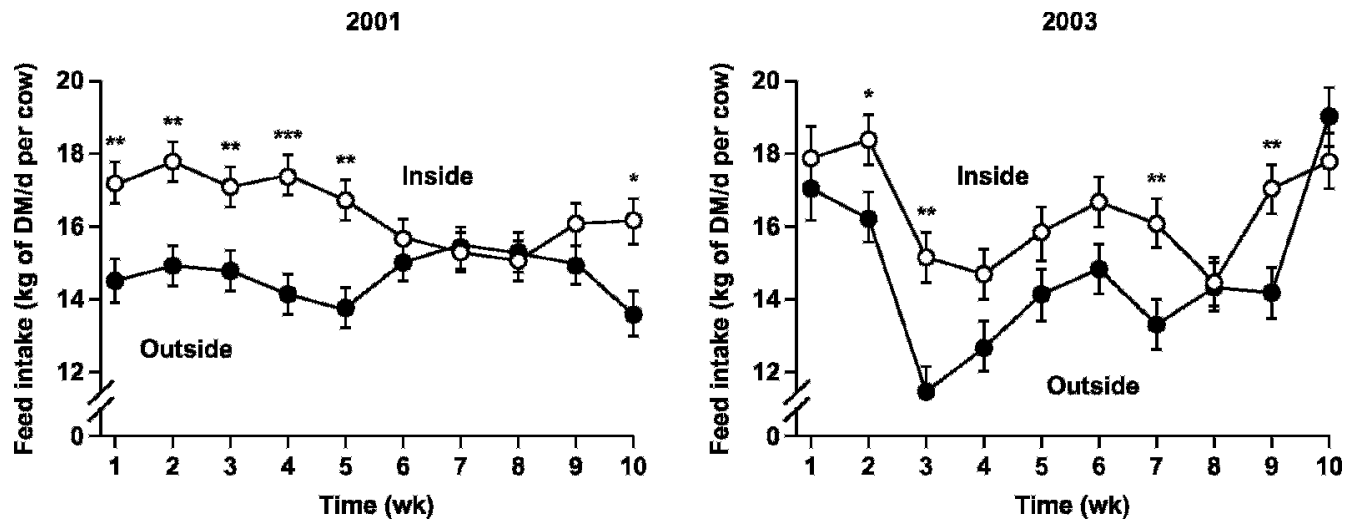

Figure 2. Intake (kg of DM/d per cow) of the partially mixed ration (PMR) in lactating Holsteins housed in the tunnel ventilation barn (inside; $\bigcirc$ ) or in an adjacent naturally ventilated free-stall barn (outside; $\bullet$ ) during the 2001 and 2003 trials. Values represent the least squares means $\pm \mathrm{SE}$ of daily observations for each group. Significant differences between groups at each time point are indicated as $* P<$ $0.05, * * P<0.01$, and $* * * P<0.001$. 
2001

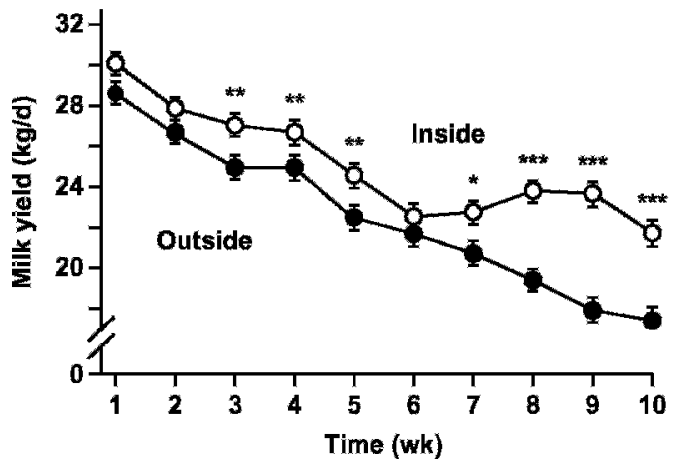

2003

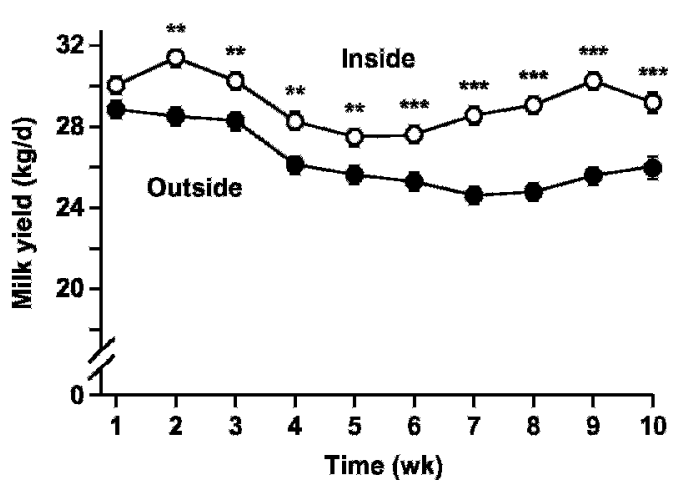

Figure 3. Milk production $(\mathrm{kg} / \mathrm{d})$ in lactating Holsteins housed in the tunnel ventilation barn (inside; $\bigcirc$ ) or in an adjacent naturally ventilated free-stall barn (outside; ) during the 2001 and 2003 trials. Values represent the least squares means \pm SE of daily observations for each group. Significant differences between groups at each time point are indicated as $* P<0.05, * * P<0.01$, and $* * * P<0.001$.

being consumed at night (Hahn, 1999), which is consistent with the observations on the importance of nighttime cooling (Fuquay, 1981; Fox and Tylutki, 1998; Keister et al., 2004). The major contribution of evaporative tunnel cooling was in reducing the duration of exposure to heat stress during the daytime (Table 2). Air velocity is commonly maintained at night in tunnel ventilation facilities to maintain air quality, but the cooling capacity of evaporative systems is greatly reduced at night, when temperatures are low and relative humidity is elevated (Smith et al., 2006). Furthermore, in the present study, pumps recycling water over the cooling pads were turned off at night to extend pad life. However, by reducing the exposure to heat stress and accumulation of heat during the daytime, the evaporative tunnel ventilation system reduced the need for nighttime cooling.

\section{Milk Production and Composition}

Before the study, milk production was similar between treatment groups for both years (Table 1). In
2001 , milk production by cows in the tunnel barn was greater as early as the third week of the trial $(P<$ 0.005 ) and remained above that of cows housed outside throughout the trial (Figure 3). Cows in both housing units were past peak production (213 \pm 53 DIM). However, as the trial progressed, production declined more rapidly for cows housed outside than for those housed in the tunnel barn (treatment $\times$ week interaction; $P<$ 0.01 ). The difference between treatments was greatest during wk 9 , with cows housed inside producing $5.7 \pm$ $0.71 \mathrm{~kg} / \mathrm{d}$ more than those housed outside $(P<0.0001)$. In addition, during the last 4 wk of the 2001 study, cows cooled by evaporative tunnel ventilation produced $4.1 \pm 0.37 \mathrm{~kg} / \mathrm{d}$ more than those cooled by fans and sprinklers $(P<0.0001)$. Thus, over the entire period, production was $2.6 \pm 0.27 \mathrm{~kg} / \mathrm{d}$ greater for cows cooled by evaporative tunnel ventilation than those cooled by fans and sprinklers $(P<0.05)$.

In 2003, production was similar for cows in both treatment groups during the first week, but during the trial there was a significant treatment $\times$ time interaction $(P<0.0001)$ in which persistence was higher for

Table 4. Milk composition and FCM production for cows housed in the tunnel barn (inside) and in an adjacent, naturally ventilated free-stall barn (outside) during the 2001 and 2003 trials $^{1}$

\begin{tabular}{|c|c|c|c|c|}
\hline \multirow[b]{2}{*}{ Variable } & \multicolumn{2}{|c|}{2001 Trial } & \multicolumn{2}{|c|}{2003 Trial } \\
\hline & Inside & Outside & Inside & Outside \\
\hline Fat, \% & $3.25 \pm 0.056$ & $3.24 \pm 0.055$ & $3.71 \pm 0.054$ & $3.61 \pm 0.038$ \\
\hline Protein, $\%$ & $3.12 \pm 0.022$ & $3.13 \pm 0.025$ & $2.96 \pm 0.017$ & $2.93 \pm 0.021$ \\
\hline Lactose, $\%$ & $4.95 \pm 0.020$ & $4.92 \pm 0.024$ & $4.90 \pm 0.025$ & $4.95 \pm 0.019$ \\
\hline $3.5 \% \mathrm{FCM}^{2}, \mathrm{~kg} / \mathrm{d}$ & $23.6 \pm 0.64^{\mathrm{a}}$ & $21.6 \pm 0.51^{b}$ & $30.3 \pm 0.64^{\mathrm{a}}$ & $27.1 \pm 0.76^{b}$ \\
\hline $\mathrm{SCC}(\times 1,000)$ & $343 \pm 51^{\mathrm{a}}$ & $467 \pm 56^{\mathrm{b}}$ & $243 \pm 60^{\mathrm{a}}$ & $479 \pm 112^{\mathrm{b}}$ \\
\hline
\end{tabular}

\footnotetext{
${ }^{\mathrm{a}, \mathrm{b}}$ Means within a trial year with a different superscript are different $(P<0.001)$.

${ }^{1}$ Data represent the least squares means $\pm \mathrm{SE}$ for cows in each group.

${ }^{2} 3.5 \% \mathrm{FCM}$ was estimated using the equation: $\mathrm{FCM}=$ milk $\times 0.4323+$ fat production $\times 16.216$ (derived from Tyrrell and Reid, 1965).
} 

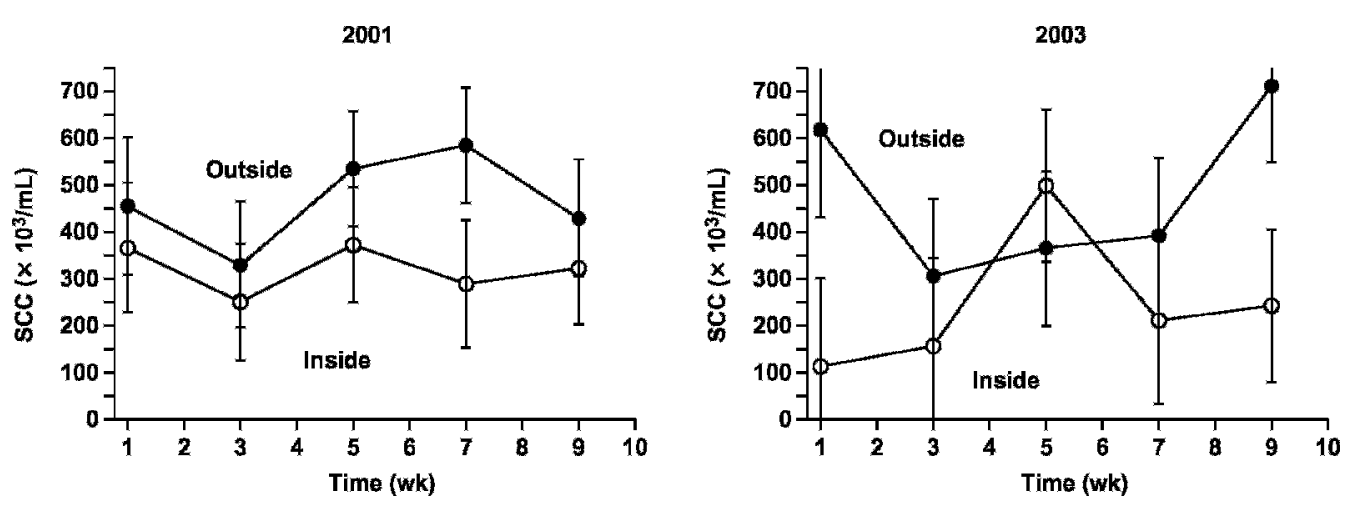

Figure 4. Somatic cells (cells $/ \mathrm{mL}$ ) in milk from lactating Holsteins housed in the tunnel ventilation barn (inside; $\bigcirc$ ) and in an adjacent, naturally ventilated free-stall barn (outside; $\bullet$ ) during the 2001 and 2003 trials. Data represent the mean \pm SE of weekly observations for each group.

cows in the tunnel barn than for those housed outside (Figure 3). The difference between treatments was greatest during wk 9 , when production by cows in the tunnel barn was $4.7 \pm 0.60 \mathrm{~kg} / \mathrm{d}$ per cow above that of cows housed outside $(P<0.0001)$. During the 10 -wk trial in 2003, cows housed inside produced $2.8 \pm 0.19$ $\mathrm{kg} / \mathrm{d}$ more than those housed outside $(P<0.0001)$. These findings are in agreement with those of Keister et al. (2004), who reported that reducing exposure to heat stress through the use of evaporative cooling could have a dramatic impact on milk production. In addition, the data suggest that evaporative tunnel ventilation technology can provide dairy cattle with relief from heat stress under conditions present in the southeastern United States.

Evaporative tunnel cooling had no effect on milk fat, protein, or lactose content in either year of the study (Table 4). During 2001, production of 3.5\% FCM was $2.0 \pm 0.45 \mathrm{~kg} / \mathrm{d}$ or $9.26 \%$ greater $(P<0.001)$ for cows housed inside than for cows housed outside. Similarly in 2003 , production of $3.5 \% \mathrm{FCM}$ was $3.2 \pm 1.1 \mathrm{~kg} / \mathrm{d}$ or $11.5 \%$ greater for cows housed inside than for those housed outside $(P<0.001)$.

In 2001, SCC for cows housed in the tunnel barn was $27 \%$ lower than for cows housed outside $(P<0.05$; Figure 4). Similarly in 2003, the SCC for cows housed inside was $49 \%$ less than for cows housed outside $(P$ $<0.05)$. There was no significant impact of week or interaction with treatment on SCC during either year of the trial. The reduction in SCC in the tunnel barn could result from reduced exposure to pathogens, but may also imply improved immune competence for cows receiving evaporative tunnel ventilation (Elvinger et al., 1992; Morrow-Tesch et al., 1996). One proposed advantage of evaporative tunnel cooling is that it decreases exposure to pathogens by removing excess water used for cooling from the environment of the cow; specifically water from misters and cooling ponds, which may collect on the teat ends and deliver pathogens. This might explain the ability of evaporative tunnel ventilation to reduce the SCC in 2001, but not in 2003, when cows housed outside were cooled with fans and shade alone. The potential impact of other differences between the 2 housing units cannot be ruled out (i.e., bedding on sand vs. rubber mats); yet, by reducing the exposure to heat stress, tunnel ventilation cooling may improve immune competence, making cows better able to combat mastitis-causing pathogens (Smith, 1983). It is interesting to note that in both years of the study, the SCC for cows housed inside were below $400 \times 10^{3}$ cells $/ \mathrm{mL}$, whereas cows housed outside were consistently above this proposed lower legal limit for class I milk (Adkinson et al., 2001).

\section{Blood Glucose and NEFA}

Concentrations of plasma glucose and NEFA were evaluated as indicators of energy status. In 2001, glucose concentration was $55.6 \pm 0.41 \mathrm{mg} / \mathrm{dL}$; it was similar in both treatment groups throughout the 10 -wk period. In 2003, plasma glucose concentrations increased steadily (linear effect of week; $P<0.0001$ ) from $56.9 \pm 1.14 \mathrm{mg} / \mathrm{dL}$ in wk 1 to $67.1 \pm 1.14 \mathrm{mg} / \mathrm{dL}$ at wk 10; however, glucose concentrations were similar in both treatment groups and there was no treatment by week interaction. Similarly, plasma NEFA concentrations were $95.5 \pm 2.09 \mu \mathrm{Eq} / \mathrm{L}$ throughout 2001 and were not affected by week of the trial, treatment group, or their interaction. Plasma NEFA concentrations, which were $151 \pm 4.3 \mu \mathrm{Eq} / \mathrm{L}$ during 2003 , were similar between treatment groups and did not change significantly as the trial progressed. Both plasma glucose and NEFA concentrations were within their normal ranges for lactating cows (Itoh et al., 1998). Feed in- 

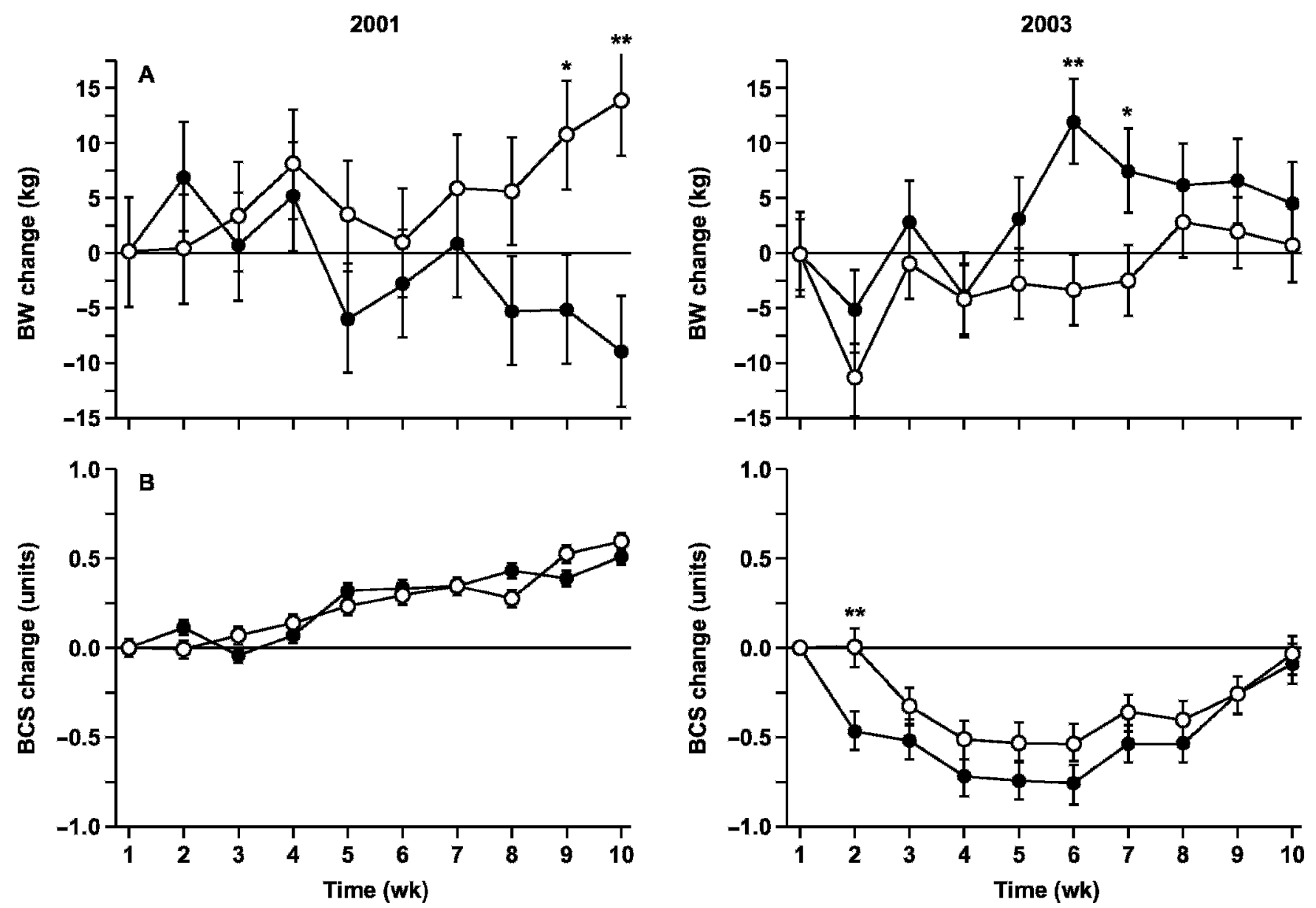

Figure 5. Change in BW (A) and BCS (B) during the 2001 and 2003 trials in lactating Holsteins housed in the tunnel ventilation barn $(\bigcirc)$ and in an adjacent, naturally ventilated free-stall barn $(-$ ). Data represent the mean \pm SE of weekly observations for each group. Significant differences between groups at each time point are indicated as $* P<0.05$, and $* * P<0.01$.

take increased in both treatment groups during the final 2 wk of 2003 , which may have been responsible for the increased glucose concentrations at that time.

\section{$B W$ and $B C S$}

The initial BW and BCS of cows in the 2001 trial were similar in both treatment groups (Table 1). During the 10-wk trial, cows housed in the tunnel barn gained $13.9 \pm 5.0 \mathrm{~kg}$, which was significantly greater than $(P<0.01)$ from the $9.1 \pm 3.6 \mathrm{~kg}$ lost by cows housed outside (Figure 5). The difference in BW gain was not reflected in BCS. Cows gained $0.56 \pm 0.05 \mathrm{BCS}$ units over the 10 -wk trial and there were no significant differences between housing units.

At the onset of the trial in 2003, cows housed outside were $0.37 \pm 0.15$ units greater in BCS $(P<0.05)$ and $30 \pm 21.3 \mathrm{~kg}$ heavier than those housed inside, but the difference in BW was not significant (Table 1). There was no significant change in BW for cows housed inside during the 10-wk trial (Figure 5), but cows housed outside gained $13.5 \pm 5.8 \mathrm{~kg}$ in the first $6 \mathrm{wk}$ of the trial $(P<0.05)$ before losing BW. Yet, over the entire 10 -wk trial period, cows gained $2.7 \pm 2.7 \mathrm{~kg}$ and the weight change was similar in both treatments. Body condition score declined during the first $4 \mathrm{wk}$ of the 2003 trial and then recovered (cubic effect of week; $P$ $<0.0001$ ). The decline in condition was more pronounced for cows housed outside; from wk 4 to 6 they averaged $0.23 \pm 0.074$ units less than cows housed inside $(P<0.05)$. Thereafter, cows in both treatment groups regained BCS, so that over the 10 -wk trial, cows lost $0.07 \pm 0.07$ units of body condition and the change was similar for both treatment groups. The apparent discrepancy between changes in BW and BCS during the 2003 trial for cows housed outside was reported previously and could be the result of alterations in water intake and a slower rumen passage rate, which have been associated with heat stress in dairy cows (Bernabucci et al., 1999). 


\section{CONCLUSIONS}

One of the most persistent questions regarding the use of tunnel ventilation technology in the southeastern United States is whether it will reliably function to cool cows given the conditions of heat and humidity experienced in the region. In the present study, evaporative tunnel ventilation reliably reduced exposure to conditions of heat stress, decreasing exposure to conditions of moderate heat stress by $84 \%$ in both years studied. The reduction in heat stress resulted in an 11 to $12 \%$ increase in feed intake, a 2.6 to $2.8 \mathrm{~kg} / \mathrm{d}$ per cow increase in milk production, and a 27 to $49 \%$ decrease in SCC compared with cows housed outside. Thus, under the conditions present at during the trial, evaporative tunnel ventilation reduced exposure to conditions of heat stress compared with cooling with fans and shade alone (2003) or with sprinklers (2001). These studies pave the way for use of evaporative tunnel ventilation in reducing the impact of heat stress and suggest that further evaluation of its economic feasibility on prepartum and lactating dairy cows in the southeastern United States is warranted.

\section{ACKNOWLEDGMENTS}

This study was conducted as part of the S-299 Southern Regional Dairy Heat Stress Project. The authors wish to thank the Mississippi Agriculture and Forestry Experiment Station (MAFES) and the Mississippi State University Department of Animal and Dairy Sciences for their generous support of the research.

\section{REFERENCES}

Adkinson, R. W., R. H. Hough, R. Graham, and A. Yilmaz. 2001. Implication of proposed changes in bulk tank somatic cell count regulations. J. Dairy Sci. 84:370-374.

Armstrong, D. V. 1994. Heat stress interaction with shade and cooling. J. Dairy Sci. 77:2044-2050.

Armstrong, D. V., P. E. Hillman, M. J. Meyer, J. F. Smith, S. R. Stokes, and J. P. Harner, III. 1999. Heat stress management in freestall barn in the Western US. Pages. 87-98 in Western Dairy Management Conference, Las Vegas, NV.

Beede, D. K., and R. J. Collier. 1986. Potential nutritional strategies for intensively managed cattle during thermal stress. J. Anim. Sci. 62:543-554.

Bernabucci, U., P. Bani, B. Ronchi, N. Lacetera, and A. Nardone. 1999. Influence of short- and long-term exposure to a hot environment on rumen passage rate and diet digestibility by Friesian heifers. J. Dairy Sci. 82:967-973.

Brouk, M. J., J. F. Smith, and J. P. Harner, III. 2003. Effect of utilizing evaporative cooling in tie-stall dairy barns equipped with tunnel ventilation on respiration rates and body temperatures of lactating dairy cattle. Pages 312-318 in Proc. 5th International Dairy Housing Conference, Am. Soc. Agric. Eng., Fort Worth, TX.
Elvinger, F., R. P. Natzke, and P. J. Hansen. 1992. Interactions of heat stress and bovine somatotropin affecting physiology and immunology of lactating cows. J. Dairy Sci. 75:449-462.

Fox, D. G., and T. P. Tylutki. 1998. Accounting for the effects of environment on the nutrient requirements of dairy cattle. J. Dairy Sci. 81:3085-3095.

Fuquay, J. W. 1981. Heat stress as it affects animal production. J. Anim. Sci. 52:164-174.

Hahn, G. L. 1999. Dynamic responses of cattle to thermal heat loads. J. Dairy Sci. 82:10-20.

Hahn, G. L., Y. R. Chen, J. A. Nienaber, R. A. Elgenberg, and A. M. Parkhurst. 1992. Characterizing animal stress through fractal analysis of thermoregulatory responses. J. Therm. Biol. 17:115-120.

Igono, M. O., and H. D. Johnson. 1990. Physiological stress index of lactating dairy cows based on diurnal pattern of rectal temperature. J. Interdiscipl. Cell Res. 21:303-320.

Igono, M. O., G. Jotvedt, and H. T. Stanford-Crane. 1992. Environmental profile and critical temperature effects on milk production of Holstein cows in desert climate. Int. J. Biometeorol. 36:77-87.

Ingraham, R. H., R. W. Stanley, and W. C. Wagner. 1975. Relationship of temperature and humidity to conception rate of Holstein cows in Hawaii. J. Dairy Sci. 59:2086-2090.

Itoh, F., Y. Obara, M. T. Rose, H. Fuse, and H. Hashimoto. 1998. Insulin and glucagon secretion in lactating cows during heat exposure. J. Anim. Sci. 76:2182-2189.

Keister, Z. O., K. D. Moss, H. M. Zhang, T. Teegerstrom, R. A. Edling, R. J. Collier, and R. L. Ax. 2004. Physiological responses in thermal stressed Jersey cows subjected to different management strategies. J. Dairy Sci. 85:3217-3224.

Lally, J. J., and M. W. Edwards. 2001. Performance differences in swine finishing facilities with natural and tunnel ventilation. Appl. Eng. Agric. 17:521-526.

Morrow-Tesch, J., N. Woollen, and L. Hahn. 1996. Response of gamma delta T-lymphocytes to heat stress in Bos taurus and Bos indicus crossbred cattle. J. Therm. Biol. 21:101-108.

National Oceanic and Atmospheric Administration (NOAA). 1976. Livestock hot weather stress. Operations Lett. C31-76. US Dept. Commerce, Natl. Weather Serv. Central Region, Kansas City, MO.

Ravagnolo, O., and I. Misztal. 2000. Genetic component of heat stress in dairy cattle, parameter estimation. J. Dairy Sci. 83:2126-2130.

SAS Institute. 1999. Users Guide: Statistics. Version 6, 4th edition. SAS Inst., Inc., Cary, NC.

Simmons, J.D., J. D. May, and B. E. Lott. 1997. Heat loss from broiler chickens subjected to various air speeds and ambient temperatures. Appl. Eng. Agric. 13:665-669.

Smith, K. L. 1983. Mastitis control: A discussion. J. Dairy Sci. 66:1790-1794.

Smith, T. R., A. Chapa, S. Willard, R. J. Williams, R. Crouch, T. Riley, and D. Pogue. 2006. Evaporative tunnel cooling of dairy cows in the Southeast. I: Effect on body temperatures and respiration rates. J. Dairy Sci. 89:3904-3914.

Stowell, R. R., C. A. Gooch, and S. Inglis. 2001. Performance of tunnel ventilation for freestall dairy facilities as compared to natural ventilation with supplemental cooling fans. Pages 29-40 in Proc. 6th Int. Symp., Am. Soc. Agric. Eng., Louisville, KY.

Turner, L. W., R. C. Warner, J. P. Chastain, and H. F. Elder. 1991. Forced evaporative cooling of dairy cows: On-farm demonstration results. Paper 91-4023. Am. Soc. Agric Eng., Albuquerque, NM.

Tyrrell, H. F., and J. T. Reid. 1965. Prediction of the energy value of cows milk. J. Dairy Sci. 48:1215-1223.

West, J. W. 2003. Effects of heat-stress on production in dairy cattle. J. Dairy Sci. 86:2131-2144.

Wildman, E. E., G. M. Jones, P. E. Wagner, H. F. Troutt Jr., and T. N. Lesch. 1982. A dairy cow body condition scoring system and its relationship to selected production characteristics. J. Dairy Sci. 65:495-501. 